\title{
The Rhetorical Structure of Short Lecture by Famous Applied Linguists Jack C. Richards Posted on YouTube
}

\author{
Idham Widodo \\ Student of English Education Postgraduate Program, Bengkulu University, Indonesia \\ idhammuris@gmail.com \\ Irma Diani \\ Lecturer of English Education Postgraduate Program, Bengkulu University, Indonesia \\ irmadiani@unib.ac.id \\ Safnil \\ Lecturer of English Education Postgraduate Program, Bengkulu University, Indonesia \\ safnil@unib.ac.id
}

\begin{abstract}
This study aims to investigate the rhetorical structure of move and step of short lecture by famous applied linguist Jack C. Richards posted on YouTube. The data of this study were 22 video-transcripts of a short lecture of Jack C Richards. The results: (1) three moves of rhetorical structure such as M1 - Introduction, M2 - Content of Short Lecture and M3 Conclusion. They are 100\% occurred in all of the data analyzed as obligatory category. (2) the most often found steps in the short lectures that occurred $100 \%$ and classified as obligatory category, such as M2SB - Argumentation of the short lecture and M3SA Summarizing the points and the steps with $60-99 \%$ percentage of occurrences as classified as conventional category, namely are M1SE - Announcing topic of oral presentation, M1SA Greeting the Audience, M2SC - Illustration of short lecture, and M2SA - Description of short lecture. The new proposed model of spoken genre analysis adapted from Ali and Singh (2019), the Sermon model by Cheong cited in Safnil (2010) and Seliman (1996) for identifying the rhetorical structure of short lecture is effective enough to capture the possible rhetorical moves and steps in a whole text of short lecture by famous applied linguist posted in YouTube.
\end{abstract}

Keywords: rhetorical structure, the lecture, move and step analysis; short lecture

\section{A. Introduction}

In communicating, language has a vital role and absolute. Language is a tool of communication; both of them are inseparable. Language is an interpretation of what the speaker wanted to deliver to their interlocutor (Syafryadin, et al. 2019; Noermanzah, et al. 2020; Syafryadin, et al. 2020). The use of good language features, whether in written as a text or in spoken as a communication will make the goals of communication running well as expected. One aspect that becomes the central focus in language learning is Discourse. Learning the discourse is not only we learn about sentence or utterances, semantically but also covered all context of linguistic feature as language is used. According to Gee (2018) discourse is the study of what we humans do with language and how we do it. It means that discourse is the study of how humans used the language for many aspects such as the way of thinking, planning, identifying, or how the differences of language used towards others, and 
to express emotions and carry out actions with the language. Moreover, when we concern with learning the discourse, we consider that there are two kinds of discourse itself; it can be spoken and written discourse.

The study of spoken and sometimes written discourse is called discourse analysis. Discourse analysis is concerned with the study of the relationship between language and the contexts in which it is used. According to Zhang (2010) spoken discourse analysis is a variety of language features and functions, which may not be explicit to everyone, are summarized to explain how people communicate effectively with the language itself. Beside, Fairclough (2003) states that written discourse is an essential part of linguistic analysis of the text. The analysis of the text is concerned with the linguistic form of the text and the distributions of different linguistic forms across different types of texts. There are a lot of researchers who are interested in researching the research about academic written text, such as books, a research proposal, a practicum report, an academic journal, and many more related. It is important because there are many forms of text that if compere one another it will occur a new kind of text.

In understanding the text we have to look from different perspectives to reach what the meaning of the whole text is? Besides, academic text has strongly related to any other discipline, just like science and technology. Even though most research focuses on analyzing written genre, such as; Wannaruk and Zhang (2016), Shi and Wannaruk (2014), Suryani (2014), and Pujianti, Safnil and Arono (2018), it is undoubtedly suggested that understanding spoken genre is also important. It is considered that only a few studies have been employed to investigate the rhetorical structure of spoken genre, such as; Ali and Singh (2019), the rhetorical pattern of Sermon (Cheong 1999 as cited in Safnil 2010), and Engineering Research Presentations: Three units of analysis by Seliman (1996). It is will bridge the researcher who interested to research in that area.

The literature reviews above are some of the many investigations about the rhetorical structure that focused on analyzing the written genre. In the other hand, there are some of the results of the investigation about the spoken genre such as follows: such as; Ali and Singh (2019), the rhetorical pattern of Sermon (Cheong 1999 as cited in Safnil 2010), and Engineering Research Presentations: Three units of analysis by Seliman (1996). As shown in the previous study about written and spoken genre analysis above, reveals that the written genre analysis has much investigated rather than spoken genre. The time ranges of the research investigation between one to another proved that spoken genre analysis is still lack of attention and needs to be expanding. In the spoken genre analysis, we have to focus on one section of the genre such as the introduction, discussion (body), and conclusion. In line with Zareva (2019), from a genre perspective, it is important to analyze the complete presentation to identify the linguistic features used to structure the whole text. Both qualitative and quantitative are suitable to use for describing and examining the frequent occurrences of the data. Therefore, the researcher feels that the investigation of the spoken genre analysis needs to do more to enrich the references about the spoken genre analysis for the further researcher. As a result, the research objectives of this study are (1). To find out what moves exist in the rhetorical structure of famous applied linguist short lectures by Jack C. Richards posted on YouTube. (2) To find out what steps exist in the rhetorical structure of famous applied linguist short lectures by Jack C. Richards posted on YouTube. (3) To find out the rhetorical pattern which more applicable for identifying the short lecture by a famous applied linguist posted on YouTube. 


\section{B. Research Methodology}

.According to Creswell, J. (2013) a mixed methods research design is a procedure for collecting, analyzing, and "mixing" both quantitative and qualitative research and methods in a single study to understand a research problem. In this research, the data is 22 videostranscripts by famous applied linguist Jack C. Richards's short lecture on YouTube. The researcher analyzed the move and steps models of rhetorical structure that exist in the transcripts of short lectures of Jack C. Richards on YouTube by using adapted three models by Saliman (1996), Sermon model (Cheong 1999 cited in Safnil 2010), Ali and Singh (2019). Then it conducted further action by way of describing and analyzing them one by one according to the theories that have been discussed in the previous chapter.

\section{B.1 Object of the Research}

The object of this research is 22 text-transcripts of famous applied linguist Jack C. Richards's of short lectures. The 22 videos of short lectures are shown in the tables below.

\section{Table 1. Topic of Short Lectures by Jack C Richards}

\begin{tabular}{|c|l|c|c|c|}
\hline NO & \multicolumn{1}{|c|}{ Topic of the Short Lectures } & Length in Minutes & Number of Words & Total \\
\hline $\mathbf{1}$ & Listening Comprehension & 04.50 & 1000 \\
\hline $\mathbf{2}$ & Communicative Competence P.1 & 04.19 & 913 \\
\hline $\mathbf{3}$ & Communicative Competence P.2 & 04.05 & 775 \\
\hline $\mathbf{4}$ & Topic in Language teaching P.2 & 04.03 & 727 \\
\hline $\mathbf{5}$ & Teacher Thinking Processes & 03.42 & 738 \\
\hline $\mathbf{6}$ & English As International Language & 03.28 & 778 \\
\hline $\mathbf{7}$ & New Englishes & 03.30 & 689 \\
\hline $\mathbf{8}$ & Vocabulary & 03.20 & 665 \\
\hline $\mathbf{9}$ & Topic in Language Teaching P.1 & 03.17 & 980 \\
\hline $\mathbf{1 0}$ & Lesson Plans & 03.15 & 679 \\
\hline $\mathbf{1 1}$ & Teaching Principle & 03.11 & 619 \\
\hline $\mathbf{1 2}$ & Observing Teaching English & 03.07 & 639 \\
\hline $\mathbf{1 3}$ & Successful Language Learner & 03.07 & 613 \\
\hline $\mathbf{1 4}$ & Task-Based Language Learning & 02.47 & 513 \\
\hline $\mathbf{1 5}$ & Grammar & 02.43 & 544 \\
\hline $\mathbf{1 6}$ & Competency-Based Instruction & 02.40 & 487 \\
\hline $\mathbf{1 7}$ & Communicative Language Teaching & 02.40 & 469 \\
\hline $\mathbf{1 8}$ & Text-Based Instruction & 02.20 & 402 \\
\hline $\mathbf{1 9}$ & The Noticing hypothesis & 02.20 & 999 \\
\hline $\mathbf{2 0}$ & Learner centered & 02.14 & 412 \\
\hline $\mathbf{2 1}$ & Textbooks & 02.08 & 423 \\
\hline $\mathbf{2 2}$ & Take a way value of a Lesson & 01.53 & 363 \\
\hline & & & \\
\hline
\end{tabular}

In the way of collecting the data, the researcher followed some steps which are mentioned and explained as follows;

1. The researcher downloads the Jack C Richards's short lectures on https://m.youtube.com

2. The researcher downloads the transcripts of Jack C Richards's short lectures on http://www.lilsubs.com/\# and prints it out.

Technique of data analysis of this study can be as follows.

1. The researcher watched the 22 videos of Jack C Richards's short lectures on YouTube. 
2. The researcher read the transcripts while watching to identify the moves of the Jack $\mathrm{C}$ Richards's short lectures based on the keywords by using adapted three models of Saliman (1996), Sermon model (Cheong 1999 cited 2010), and Ali and Singh (2019).

3. The researcher read the transcripts of the short lecture of Jack c Richard to identify the step based on the keyword to identify the steps of rhetorical pattern based on the adapted three models by Saliman (1996), Sermon model (Cheong 1999 cited in Safnil 2010) and Ali and Singh (2019).

4. The researcher assisted by an independent-rater in analyzing the transcripts by triangulation technique in order to obtain more valid data.

5. The researcher randomly takes $25 \%$ of the entire data to be analyzed referring to Indah (2018) in order to reach the level of agreement between the researcher and the independent rater.

6. The researcher tabulates all of the data frequency of moves by using Cohen Kappa theory.

7. The researcher counts the frequency of move and step agreement between the independent rater manually.

8. The researcher counted the percentage of step in move by:

Percentage $(\%)=\mathrm{NO} /(\mathrm{TD}) \mathrm{X} 100 \%$

Noted:

$N O=$ Number of occurred

$T D=$ Total of Data

9. The researcher tabulates the data frequency and provides the example move and step found.

10. The researcher concludes the finding.

The Data validation technique used in this research is by involving an Independent-rater. After the researcher and Independent-rater finished analyzing the move and step in the short lecture the data presented by Cohen's Kappa principle. To know the strength of the data agreement, the scale value formulated as follow:

$$
K=\frac{\operatorname{Pr}(a)-\operatorname{Pr}(e)}{1-\operatorname{Pr}(e)}
$$

By means:

$$
\begin{array}{ll}
\mathrm{K} & =\text { Agreement Frequency } \\
\operatorname{Pr}(\mathrm{a}) & =\text { the Overall Probability of Same Agreement } \\
\operatorname{Pr}(\mathrm{e}) & =\text { the Overall Probability of Random Agreement }
\end{array}
$$

\begin{tabular}{|l|l|}
\hline \multicolumn{1}{|c|}{ Kappa $(\mathbf{K})$} & \multicolumn{1}{|c|}{ Strength of Agreement } \\
\hline$<0.20$ & Very Poor \\
\hline $\mathbf{0 . 2 0}-\mathbf{0 . 3 9}$ & Poor \\
\hline $\mathbf{0 . 4 0}-\mathbf{0 . 5 9}$ & Fair \\
\hline $\mathbf{0 . 6 0}-\mathbf{0 . 7 9}$ & Good \\
\hline $\mathbf{0 . 8 0}-\mathbf{1 . 0 0}$ & Excellent \\
\hline
\end{tabular}

Furthermore, the frequency of the occurrences distinguished whether move and step in the short lecture of Jack C. Richards were adequately classified as optional, conventional, or obligatory. If the moves occurred less than $60 \%$ in all of the research object analyzed, it will be categorized as optional, then if they occurred between 60-99\%, they were categorized as conventional, and if the moves occurred in all of the object analyzed, they were categorized as obligatory, (Kenoksilapatham 2005, cited in Indah 2018). The last, the researcher focused on the steps which classified as obligatory and conventional categorized to be looked for as the research analysis target. 


\section{Results and Discussion \\ 1. Results}

The Independent-rater worked independently to code the data $(25 \%$ of the entire sample of the data analysis transcripts) was taken randomly selected from 22 of all the data analyzed with different topic of short lecture (henceforth SL) in order to reach the good level of agreement between the researcher and the independent rater, referring to Indah (2018). The result of Cohen's Kappa statistic (K) showed excellent agreement with a little difference in which $\mathrm{K}$ equal $100 \%$ by researcher and $0.88 \%$ by independent-rater as seen in the table below:

Table 2. Cohen's Kappa statistics result

\begin{tabular}{|l|c|c|c|c|c|}
\hline & $\begin{array}{c}\text { The 25\% } \\
\text { of SL } \\
\text { sample }\end{array}$ & $\begin{array}{c}\text { Frequency of } \\
\text { move and } \\
\text { step } \\
\text { agreement }\end{array}$ & $\begin{array}{c}\text { Frequency of } \\
\text { move and } \\
\text { step } \\
\text { disagreement }\end{array}$ & $\mathbf{K}$ & $\%$ \\
\hline Researcher & 5 & 33 & 0 & 1.00 & $100 \%$ \\
\hline $\begin{array}{l}\text { Independe } \\
\text { nt rater }\end{array}$ & 5 & 30 & 3 & 0.88 & $88 \%$ \\
\hline
\end{tabular}

Based on the Table 2 above, the difference of $\mathrm{K}$ between researchers (1.00) and Independentrater $(0.88)$ was 0.12 . This finding also means that $0.88 \%$ of SL data evaluation between researcher and independent-rater was matched. It was shown by Kappa value about $0.88 \%$, it was confirmed an excellent level of agreement. Moreover, the analysis results of this research found that the frequency of rhetorical move and step in the short lectures have variation in the number of occurrences for each of the move and step existed in 22 data of short lecture videotranscripts. For more details shown in the table below;

\section{A. The Frequency of Move in the short lecture}

Table 3: Frequency of Move in the short lectures

\begin{tabular}{|c|l|c|c|l|}
\hline \multicolumn{2}{|c|}{ Move } & Frequency & Percentage & Category \\
\hline M1 & $\begin{array}{l}\text { INTRODUCTION } \\
\text { (Listeners Orientation and } \\
\text { Content Orientation) }\end{array}$ & 20 & $90 \%$ & $\begin{array}{l}\text { conventio } \\
\text { nal }\end{array}$ \\
\hline M2 & $\begin{array}{l}\text { BODY } \\
\text { (Content of short lecture) }\end{array}$ & 22 & $100 \%$ & obligatory \\
\hline M 3 & $\begin{array}{l}\text { CONCLUSION } \\
\text { (Concluding) }\end{array}$ & 22 & $100 \%$ & obligatory \\
\hline
\end{tabular}

As indicated in tables 3 above, there were three moves that existed in a short lecture. Firstly, Move 1 (M1) - Introduction (Listeners orientation and Content orientation) has consisted of two sub-moves such as M1A - Listeners Orientation and M1B - Content Orientation. Both of them have a good frequency of occurrence in the Move 1; it could be categorized as a conventional category. Next, the researcher found that Move 2 (M2) - Body (content of short lecture) and the Move 3 (M3) - Conclusion reached the top of maximum occurrence equal with the total number of the data analyzed and classified as obligatory category. 


\section{B. Frequency of Step in Move 1 (Introduction)}

Table 4: Frequency of step in Move 1 (Introduction)

\begin{tabular}{|c|c|c|c|c|}
\hline \multicolumn{2}{|c|}{ Move1 (M1) } & Frequency & Percentage & Category \\
\hline \multirow[t]{3}{*}{ Step } & $\begin{array}{l}\text { A-Greeting the } \\
\text { Audience }\end{array}$ & 19 & $86 \%$ & $\begin{array}{l}\text { convention } \\
\text { al }\end{array}$ \\
\hline & B - Reciting Prayer & $\mathbf{0}$ & $0 \%$ & optional \\
\hline & $\begin{array}{l}\mathbf{C}-\text { Introducing oneself } / \\
\text { other speaker }(s)\end{array}$ & $\mathbf{0}$ & 0\% & optional \\
\hline \multirow[t]{3}{*}{ Step } & $\begin{array}{l}\text { D - Leading audience } \\
\text { into the content }\end{array}$ & 11 & $50 \%$ & optional \\
\hline & $\begin{array}{l}\mathbf{E}-\text { Announcing topic of } \\
\text { oral presentation }\end{array}$ & 20 & $90 \%$ & $\begin{array}{l}\text { convention } \\
\text { al }\end{array}$ \\
\hline & $\begin{array}{l}\text { F - Outlining structure / } \\
\text { Indicating scope }\end{array}$ & 2 & $9 \%$ & optional \\
\hline
\end{tabular}

As can be noticed from the table 4 above, every step which occurred in Move 1 (Introduction) have variant of frequency and percentage. As clear as in the following example below;

\section{Example 1 of M1SA - Greeting the Audience}

$\underline{\text { Hello }}$, today I'd like to talk about listening comprehension, something that you are doing right now (SL.No.1 - Listening Comprehension).

The word bold and underlined above such "Hello" as a linguistic signal which indicates that the speaker began the speech as an oral presentation by greeting the viewer or audience. Another one of step in M1B was a step that aimed to announce the audiences or viewer into the topic of discussion or M1SE - Announcing the topic of oral presentation. As seen in the following example below;

Example 2 of M1SE - Announcing the topic of oral presentation.

today I'd like to talk about listening comprehension, something that you are doing right now (SL No.1 - Listening Comprehension).

The phrase of "Today I'd like to talk about" indicated that this kind of step was the speaker announced the topic verbally (Rowley Jolivet, \& Carter-Thomas, 2005). The Common expression "I'd like to talk to", which existed in almost the entire short lecture, the steps that proved to be quite important in the M1 - Introduction section as conventional category.

1.C. The Frequency of Step in Move 2 (M2) Body - Content of short lecture

Table 5: Frequency of Step in Move 2 (M2) Body - Content of short lecture

\begin{tabular}{|c|l|c|c|c|}
\hline \multicolumn{1}{|c|}{ Move 2 (M2) } & Frequency & Percentage & Category \\
\hline Step & $\begin{array}{l}\text { A - Description of short } \\
\text { lecture }\end{array}$ & $\mathbf{1 6}$ & $\mathbf{7 2 \%}$ & conventional \\
\cline { 2 - 5 } & $\begin{array}{l}\text { B - Argumentation of short } \\
\text { lecture }\end{array}$ & $\mathbf{2 2}$ & $\mathbf{1 0 0 \%}$ & obligatory \\
\cline { 2 - 5 } & $\begin{array}{l}\text { C - Illustration of short } \\
\text { lecture }\end{array}$ & $\mathbf{1 7}$ & $\mathbf{7 7 \%}$ & conventional \\
\hline
\end{tabular}


As can be noted in Table 5 above, the steps clearly proved that the content of the short lecture, Move 2 (M2) - Body contained much information on the topic of the short lecture discussed. As detail as shown in the following example below:

Example 4 of M2SA - Description of short lecture

Linguistic competence refers to the ability we have to create accurate sentences in the language and so if you look at grammar books the short of books your students study reference books and so on,

(SL No.2 - Communicative Competence Part 1).

The bold and underlined phrase above "refers to" was indicates that the speaker wants to describe the meaning of the topic discussion. The researcher found that the form of utterances that followed was a kind of argumentation, it means that the speaker willing to strengthen his previous statement.

Example 5 of M2SB - Argumentation of short lecture

Well, to understand it I think we need to sort of rewind a little to look at more traditional approaches to teaching those that are built around a grammar paradigm where each lesson has a sort of presentation practice and production phase based on the grammar focus of the lesson task-based teaching really goes the other way around it starts if you like with tasks that students do and from their performance on those tasks the teacher identifies what language the students need what language could be developed out of their task performance..,

(SL No. 14 - Task-based language learning).

The phrase of Well to understand it I think......., indicated that the speaker wanted to argue and provided logical reasoning or a persuasive speech toward the topic (Cheong 1999 cited in Safnil 2010). The last one step which included in the M2-Content of Short Lecture was M2SC - Illustration of the Short Lecture. As written below.

Example 6 of M2SC - Illustration of short lecture

for example I'm working with some Korean learners at the moment and they tend to misplace adverbs so instead of saying I just arrived, they'll say just I arrived. It probably comes from the word order of Korean.

(SL No. 4 - topic in language teaching).

The underlined word for example above was indicated that the speaker wanted to illustrate the argumentation by explaining the content of a short lecture in order to make it more interesting and easier to be understood. Furthermore, the closing statement from the speaker was the stressing point and quite important that the listeners or the viewers can take away the lesson from it. As seen in the table below; 


\section{D. The Frequency of Step in Move 3 (M3) - Conclusion}

Table 6: Frequency of Step in Move 3 (M3) - Conclusion

\begin{tabular}{|l|l|c|c|l|}
\hline \multicolumn{2}{|c|}{ Move 3 (M3) } & Frequency & Percentage & Category \\
\hline Step & A - Summarizing the points & $\mathbf{2 2}$ & $\mathbf{1 0 0 \%}$ & obligatory \\
\hline & B - End Signal / Thank you & $\mathbf{5}$ & $\mathbf{2 2 \%}$ & optional \\
\hline
\end{tabular}

As can be concluded from the table 6 above, the SA - Summarizing the points in the Move 3 hit the 22 times occurred or $100 \%$ existed in the all data analyzed and classified as obligatory category. It means that the speakers closed the short lecture with an important point of the topic which can enrich the knowledge of the audiences or the viewers.

Example 7 of M3SA - Summarizing the points

So it's important to identify some highlight some key points at the end of a lesson that you really want the students to remember and take away from that lesson something that made it worthwhile for them to come to class for that day. (SL No.22 - take away the lesson)

The word bold and the underlined statement above showed that the speaker was close to end up his / her speech as an oral presentation. The linguistic signal of "So" in the beginning of the paragraph indicates that the speaker uttered the last statement and the underlined utterances such as some highlight some key points at the end of a lesson and Something that made it worthwhile for them to come to the class for that day were the stressing point to conclude the topic discussion, SA - Summarizing the point. Discourse marker "So" which are the feature of the spoken language were used by the speakers to engage with the audience Ali and Singh (2019). In sum, the analysis revealed that the rhetorical structure of move and step in short lecture of Jack C Richards posted on YouTube were found in the 22 video-transcripts as the data of this research.

\section{Discussion}

The research question was to find out what moves and the steps which exist in short lectures by famous applied linguist Jack C. Richards posted on YouTube. The researcher focused on the move and steps which classify as obligatory and conventional category. The First, there were 3 of rhetorical move of Jack C Richards found in his short lecture speech as an oral presentation posted on YouTube. The First, Move 1 (M1) - Introduction. This move was consisted by 2 sub-moves; M1A - Listener Orientation and M1B - Content Orientation. Secondly, the Move 2 (M2): Body - Content of short lecture. Thirdly, the Move 3 (M3): Conclusion. The move three moves existed in all of the short lecture; it's categorized as obligatory and Conventional. This also proves that in analyzing a short lecture as the data of this research the three of the moves mentioned above always existed in a whole of the text.

The second was to find out what the steps are often found in each move of short lectures by famous applied linguist Jack C Richard posted on YouTube? The step of the short lecture with the most often found in short lecture of Jack C Richards is the steps that are classified as an obligatory category. The first is the step of M2SB - Argumentation of short lecture, and the step of M3SA - Summarizing the points. Both of the steps hit 100\% percentage of occurrences classified as obligatory category. The second often found in the steps of M1SE Announcing the topic of oral presentation, M1SA - Greeting the Audience, M2SA Description of short lecture, and M2SC - illustration of short lecture. The steps above are reached around 60-99\% percentage of occurrence and classified as conventional category. 
Moreover, the use of personal pronouns such as I, we, our, you, and your, represent of positive politeness strategy to provide a feeling of comprehensiveness to the audience (Fortanet, 2014). The use of 'I' refers to the speaker while 'you' and 'your' indicates to the audience or viewers where the personal pronouns of just to reinforce the personal connections or engagement between the speaker and the viewer, (Ali and Singh, 2019). Similarly, the use of personal pronouns as they are involved with their viewer as an oral presentation is characterized as representing involvement, (Chafc, 1982).

The proposed model (see figure 3.pg 26) above is quite applicable to be used in identifying the short lecture by famous applied linguist Jack C Richards posted on YouTube. However, there are two steps that are not applicable well such as M1SB - Reciting Prayer and M1SC - Introduction of oneself / other speakers $(s)$. The proposed model (see figure 3 pg.26) answered the third research question of this research.

\section{Conclusion and Suggestion}

Conclusions are drawn as follows:

1. There are three moves found in the rhetorical structure of Jack C Richards short lecture posted on YouTube. The first, Move 1 (M1): INTRODUCTION - Listener orientation and Content orientation. The second is the Move 2 (M2): BODY - Content of short lecture. The Last, the Move 3: CONCLUSION - Concluding.

2. The steps of short lectures which the most often found in short lecture of Jack C Richards are the steps that are classified as Obligatory category. They are M2SB Argumentation of short lecture and M3SA - Summarizing the points. Both of the steps reached $100 \%$ percentages of occurrences. The second is often found in the steps of M1SA Greeting the Audience, M1SE - Announcing Topic of Oral Presentation, M2SA Description of Short Lecture, and M2SC - illustration of Short Lecture. The second often found of steps previously have reached around 60-99\% percentages and classified as Conventional category.

However, the steps that are fundamental and obligatory are step M1SA, M1SE, M2SA, and M3SA. The "Greeting to Audience", "Announcing the topic" "Description of short lecture" and "Summarizing the points" are the steps that very important and obligatory in a whole oral presentation because the speaker needs to orientate and setting up the scope and the core of the oral presentation as a spoken genre by greeting the audience or viewer but also the speaker should announce the topic, define it and summarize the point as something that could be taken away by the listeners or viewers as a lesson.

3. The researcher conclude that the more applicable model for identifying the rhetorical structure of short lecture by other famous applied linguist posted on YouTube as seen as below;

\section{Introduction}

Move 1: Listener Orientation

Step A - Greeting the Audience

Move 2: Content Orientation

Step A - Leading audience into the content

Step B - Announcing the topic of oral presentation

2. Body

Step C - Outlining structure / Indicating scope

Move 3: Content of short lecture

Step A - Description of short lecture

Step B - Argumentation of short lecture

Step C - Illustration of short lecture 


\section{Conclusion}

Move 4: Concluding

Step A - Summarizing the points

Step B - Closing remark

\section{Figure 4: The new proposed model for identifying the rhetorical structure of short lecture}

In short, one's patterns of rhetorical structure could differ from others. it because everyone has different perspectives and uttering ideas either. The new proposed model as shown previously (See figure 4) could be a model for identifying the rhetorical structure as a spoken genre from others applied linguists who posted on YouTube.

\subsection{Suggestion}

There are some suggestions given as follow:

1. Lecturer

Pedagogically the result of this research are not only good material supply for the class of Discourse in terms of spoken genre analysis, but also as material for improving language competence such as; listening comprehension and speaking skill. From the genre perspective, this finding made the possibility to the researcher for identifying the linguistic featured used in the short lecture completely.

2. Further Researcher

The Proposed model for identifying the rhetorical move and step it could be used for theory-based in conducting the similar research with different aspect, such as a kind of oral presentation or speech of another famous applied linguist posted on YouTube.

\section{References}

Ali, M., and Singh, M. (2019). A genre-based investigation of the introduction sections of academic oral presentation. Asian Journal of University Education. 15(2), 95-125.

Creswell, J. W. (2013). Research design: Qualitative, quantitative, and mix methods approaches. USA. SAGE Publication Inc.

Chafc, W. (1982). Integration and involvement in speaking. writing and oral literature. In D. Tannen (ED). Spoken and written language: Exploring orality and literacy, 35-54, Norwood. NJ:Ablex

Fairclough, N. (2003). Analyzing discourse textual analysis for social research. London and NY. Routledge

Fortanet, I. (1997). The use of "We" in university lectures: reference and function. English for Specific Purposes, 23, 45-46

Gee P. James (2018). Introducing to discourse analysis from grammar to society. NEW YORK. Routletge

https://www.youtube.com/results?search_query=jack+c+richard+short+lectures retrieved on February 12, 2020 at $23.15 \mathrm{pm}$

http://www.lilsubs.com/ retrieved on February 12, 2020 at $23.15 \mathrm{pm}$

Kamarudin and Suryani. (2014). Rhetorical structure in academic research writing by nonnative writers. International Journal of Higher Education in Malaysia, 3(1), 3.

Kemendikbud. (2016). Silabus mata pelajaran sekolah menengah pertama/madrasah tsanawiyah [Syllabus for junior high school/madrasah tsanawiyah]. Jakarta: 
Kementrian Pendidikan dan Kebudayaan Direktorat Jenderal Guru dan Tenaga Pendidikan

Noermanzah, N., Syafryadin, S., Castrena, O. W., \& Abid, S. (2020). Rhetoric structure of the master of ceremony and the function of the akikah event in Lubuklinggau City. Journal of English Education and Teaching, 4(2), 232-247.

Pujiyanti A. I., Safnil., and Arono. (2018). rhetorical structure analysis on introduction chapters of english master theses by indonesian postgraduate students. IJEE (Indonesian journal of English education), 5 (2), 143-146.

Rowley-Jolivet, E. \& Carter-Thomas, S. (2005). The rhetoric of conference presentation introductions: context, argument and interaction. International Journal of Applied Linguistics, 15, 45-70.

Safnil, (2010). Pengantar analisis rhetorika teks. Bengkulu.FKIP UNIB

Seliman, S. (1996). The genre and the genre expectations of engineering oral presentations related to academic and professional context. Unpublished Dissertation, University of Stirling.

Syafryadin, H., \& Salniwati, A. R. A. P. Digital storytelling implementation for enhancing students' speaking ability in various text genres. International Journal of Recent Technology and Engineering (IJRTE). 8(4), 3147-3151.

Syafryadin, S., Martina, F., \& Salniwati, S. (2020). Compensation strategies in speaking activities for non-English department students: poor and competent speakers. JEES (Journal of English Educators Society), 5(2), 109-116.

Wannaruk and Zhang. (2016). Rhetorical structure of education research article methods sections. PASAA: Journal of Language Teaching and Learning in Thailand, 51. 155184.

Wannaruk and Shi, (2014). Rhetorical structure of research Article in Agriculture Science. English Language Teaching. Canadian Center of Science and Education. 7(8), 1.

Zareva, A. (2019). Lexical complexity of academic presentgations: similarities despite situational differences. Journal of Second Language Studies, 2(1), 72-93.

Zhang, Y. (2010). An analysis of spoken discourse between two native speakers. review of european studies. School of Foreign Languages, Qingdao University of Science and Technology. 6(2), 70. 